\title{
Effect of p27 Deficiency and Rapamycin on Intimal Hyperplasia: In Vivo and In Vitro Studies Using a p27 Knockout Mouse Model
}

\author{
Mercè Roqué, Ernane D. Reis, Carlos Cordon-Cardo, Mark B. Taubman, \\ John T. Fallon, Valentin Fuster, and Juan J. Badimon \\ Cardiovascular Biology Research Laboratories (MR, JTF, JJB), Cardiovascular Institute (MR, MBT, VF, JJB), and \\ Departments of Surgery (EDR) and Pathology (JTF), Mount Sinai School of Medicine, and Department of Pathology \\ (CC-C), Memorial Sloan-Kettering Cancer Center, New York City, New York
}

\begin{abstract}
SUMMARY: Rapamycin, an immunosuppressant and antiproliferative agent, reduces intimal hyperplasia after arterial injury in animal models and in a preliminary study in humans. Rapamycin treatment reportedly increases expression of p27, a cyclin-dependent kinase inhibitor. This mechanism was tested using a p27-deficient (p27 -/-) murine model. Aortic smooth muscle cells from wild-type (WT) and p27 -/- mice were isolated and cultured. Cell proliferation, assessed by cell count and ${ }^{3} \mathrm{H}$-thymidine incorporation, was inhibited significantly by rapamycin in WT and p27 -/- cells at concentrations of $1 \mathrm{ng} / \mathrm{ml}, 10$ $\mathrm{ng} / \mathrm{ml}$, and $100 \mathrm{ng} / \mathrm{ml}(p<0.05$, versus control). The in vivo effect on intimal hyperplasia was studied in p27 -/- and WT mice after femoral artery transluminal injury. Rapamycin treatment was started 2 days before injury and maintained for 2 weeks (1 $\mathrm{mg} / \mathrm{kg}$ per 48 hours, ip). No significant differences in intima-to-media ratio were found between WT (1.1 \pm 0.1$)$ and p27 -/ - mice $(1.0 \pm 0.1) 4$ weeks after injury. Rapamycin significantly $(p<0.05)$ reduced intima-to-media ratios in both WT $(0.7 \pm 0.1)$ and p27 $-/-$ mice $(0.5 \pm 0.1)$, compared with untreated mice. p27 deficiency did not alter the arterial wall proliferative response to injury. The inhibitory effect of rapamycin on intimal hyperplasia occurred via a p27-independent mechanism. The in vitro data showed that this effect was mediated through decreased proliferation and enhanced apoptosis. (Lab Invest 2001, 81:895-903).
\end{abstract}

$E$ xcessive vascular smooth muscle cell (SMC) proliferation is a feature of restenosis after percutaneous coronary interventions and is present in spontaneous atherosclerotic lesions (Casscells, 1992; Foegh and Virmani, 1993; Ross, 1999). Control of cell proliferation by targeting cell-cycle regulation has been proposed as a therapeutic strategy to prevent development of intimal hyperplasia (Braun-Dullaeus et al, 1998; Chang et al, 1995; Chen et al, 1997; Li and Brooks, 1999; MacLellan and Majesky, 1997; Mann et al, 1999; Morishita et al, 1994.

Cyclin-dependent kinase inhibitors (CDKIs) are critical regulators of cell-cycle progression. These proteins bind to complexes formed by cyclins and cyclindependent kinases (CDKs), inhibiting their enzymatic activity and thereby inducing cell-cycle arrest (Sherr and Roberts, 1995). p2 $7^{\mathrm{kip} 1}$ is an ubiquitous CDKI with a predominant role in regulating G1/S phase transition, determining cell entry into $S$ phase or withdrawal from the cycle (Koff et al, 1993; Polyak et al, 1994).

Received March 9, 2001

This work was supported in part by a grant-in-aid from the Spanish Heart Association (MR) and the National Institutes of Health (SCOR NIH P5O HL54469) to JJB and JTF.

Address reprint requests to: Dr. Juan J. Badimon, Cardiovascular Biology Research Laboratory, Zena and Michael A. Wiener Cardiovascular Institute, The Mount Sinai School of Medicine, New York, NY 10029-6574. E-mail:Juan.Badimon@mssm.edu
Mitogenic stimuli, such as platelet-derived growth factor (PDGF) and interleukin-2, down-regulate p27 (Nourse et al, 1994). Low intracellular levels of free p27 enable retinoblastoma protein ( $\mathrm{pRB}$ ) hyperphosphorylation by cyclin-CDK complexes, subsequent release of E2F transcription factor, and cell replication (Polyak et al, 1994).

Rapamycin is a potent growth inhibitor that impairs progression through G1/S transition (Marx et al, 1995). Proposed mechanisms of action include inhibition of p70S6 kinase, impairment of pRB hyperphosphorylation, and prevention of p27 down-regulation (Dumont and Su, 1996; Marx et al, 1995). Regulation of p27 levels is thought to be critical for the antiproliferative activity of rapamycin (Luo et al, 1996). We previously demonstrated that rapamycin inhibits intimal hyperplasia after coronary angioplasty in the pig, and is associated with increased p27 levels and decreased phosphorylation of pRB in the vessel wall (Gallo et al, 1999). More recently, a pilot human study reported a lack of neointimal proliferation after implantation of rapamycin-coated stents (Sousa et al, 2001).

Our current study examines the effect of p27 on neointimal formation after injury and whether lack of p27 influences the antiproliferative effect of rapamycin. We used a previously characterized p27-deficient murine model (Fero et al, 1996; Kiyokawa et al, 1996; Nakayama et al, 1996). Additionally, the effects of rapamycin on wild-type (WT) and p27-deficient (p27 
-/-) mouse vascular SMC proliferation and apoptosis were studied in vitro. The inhibitory effect of rapamycin seems to be mediated through decreased proliferation and enhanced apoptosis, by p27-independent mechanisms. In vivo, p27 deletion did not alter the proliferative response to injury induced by transluminal endothelial denudation to the femoral artery.

\section{Results}

\section{Effect of p27 Deletion on the Proliferative Response after Arterial Injury}

By 28 days after transluminal injury, mouse femoral arteries developed a robust proliferative response. In WT mice ( $n=20$ arteries), intimal area was $8746 \pm$ $736 \mu \mathrm{m}^{2}$, and the intima-to-media (I/M) ratio was 1.1 \pm 0.1 . This translated into luminal narrowing of $23 \% \pm$ $2 \%$ (Figs. $1 \mathrm{~A}$ and $2, \mathrm{~A}$ and $\mathrm{B}$ ). In p27 $-/-$ mice $(n=33$ arteries), intimal area was $9378 \pm 776 \mu \mathrm{m}^{2}, \mathrm{l} / \mathrm{M}$ ratio was $1.0 \pm 0.1$, and luminal narrowing was $23 \% \pm 2 \%$ ( $p=$ not significant versus WT) (Figs. $1 \mathrm{~B}$ and $2, \mathrm{~A}$ and B). No significant differences between WT and p27 knockout mice were observed regarding vessel area, medial area, lumen area, lengths of internal and external elastic laminae, or lesion composition.

\section{Inhibitory Effects of Rapamycin on Intimal Hyperplasia}

Rapamycin induced a significant reduction in the intimal response after injury. In WT mice ( $n=25$ arteries) compared with control treatment, rapamycin reduced the intimal area $\left(5875 \pm 830 \mu \mathrm{m}^{2} ; p=0.01\right)$, $\mathrm{I} / \mathrm{M}$ ratio $(0.6 \pm 0.1 ; p=0.002)$, and luminal narrowing $(15 \% \pm 2 \% ; p=0.02$ ) (Figs. $1 \mathrm{C}$ and $2, \mathrm{~A}$ and $\mathrm{B})$. p27 $-/-$ mice $(n=16)$ treated with rapamycin also exhibited significant reductions of intimal area $(5117 \pm 1249$ $\left.\mu \mathrm{m}^{2} ; p=0.007\right), \mathrm{l} / \mathrm{M}$ ratio $(0.5 \pm 0.1 ; p=0.001)$, and luminal narrowing $(12 \% \pm 3 \% ; p=0.006)$ versus control-treated p27 -/- mice (Figs. 1D and 2, A and B).

\section{Antiproliferative Effect of Rapamycin on Mouse Aortic SMC}

Antiproliferative effects of rapamycin in aortic SMC from WT and p27 -/- mice were investigated. Aortic SMC were cultured in 10\% fetal bovine serum (FBS) with different concentrations of rapamycin. Rapamycin inhibited proliferation of aortic SMC from WT (Fig. $3 \mathrm{~A})$ and p27 -/- (Fig. 3B) mice at the three concentrations used $(1,10$, and $100 \mathrm{ng} / \mathrm{ml})$. In both cell types, rapamycin also significantly inhibited PDGF-inducible DNA synthesis, determined by ${ }^{3} \mathrm{H}$-thymidine incorporation (Fig. 4).

Immunohistochemical assessment of Ki67 proliferative index at baseline conditions showed that 10\% \pm $1 \%$ of WT SMC were immunoreactive for Ki67, compared with $11 \% \pm 3 \%$ Ki67-immunoreactive p27 -/cells. Rapamycin added to the culture media for 72

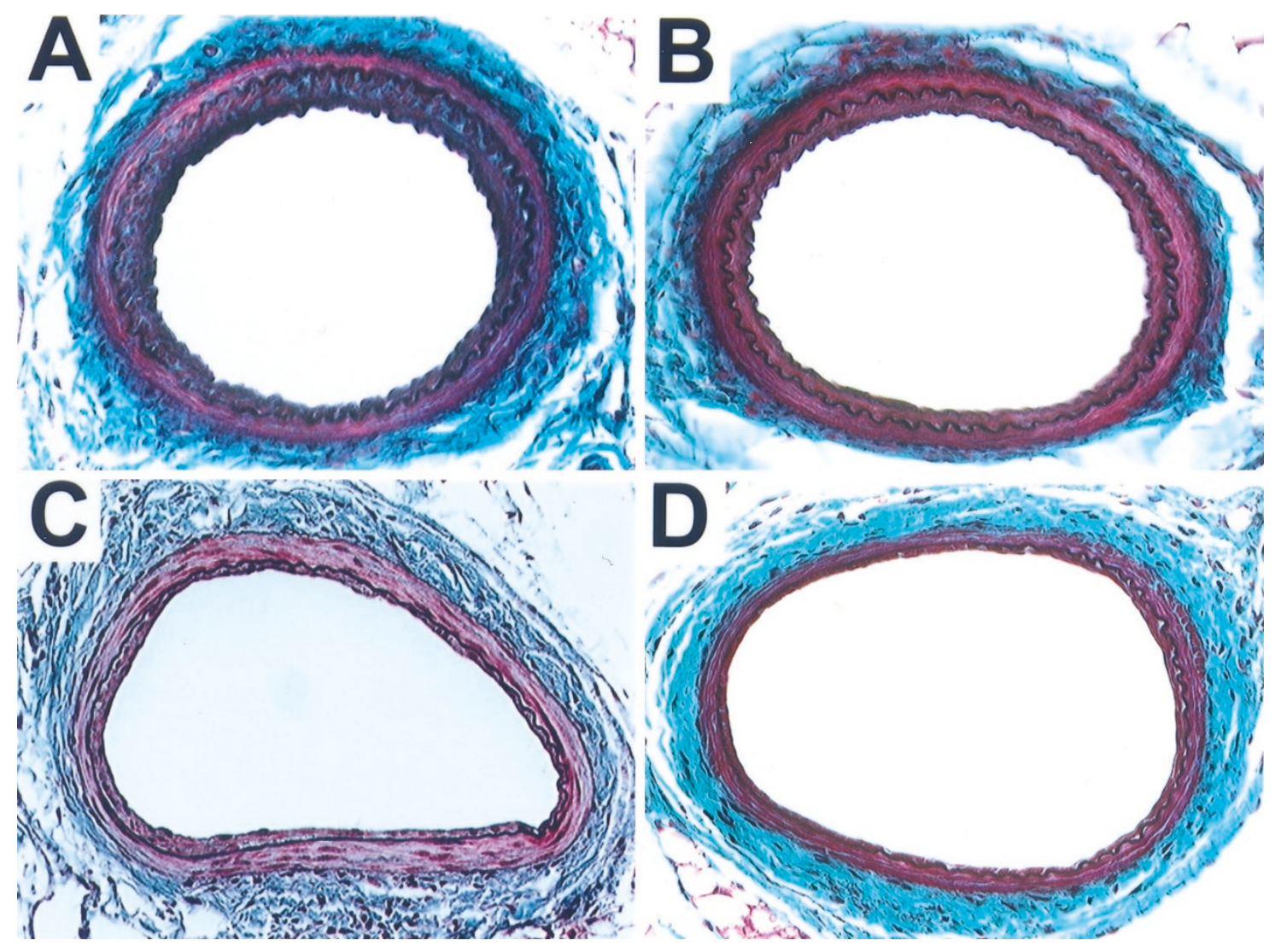

Figure 1.

Proliferative response of mouse femoral arteries 28 days after transluminal injury. Representative photomicrographs illustrating the proliferative response of wild-type (WT) (A and $C$ ) and p27 - /- mice (B and D). A and B, vehicle treated; $C$ and D, rapamycin treated. Original magnification, $\times 400$. 
A

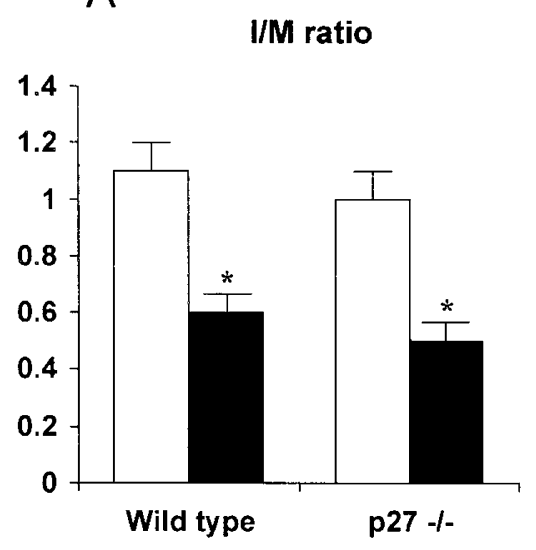

B

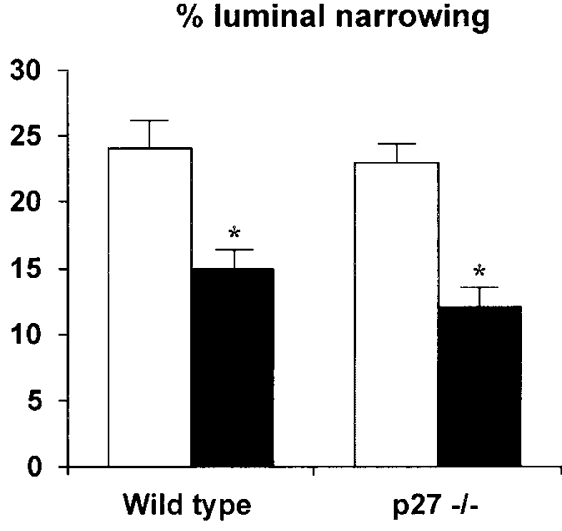

Control

Rapamycin, $1 \mathrm{mg} / \mathrm{Kg}$

${ }^{*} p<0.05$

Figure 2.

Effect of rapamycin on intima-to-media ratio (I/M) (A) and luminal narrowing (B) in WT and p27 -/- mice.
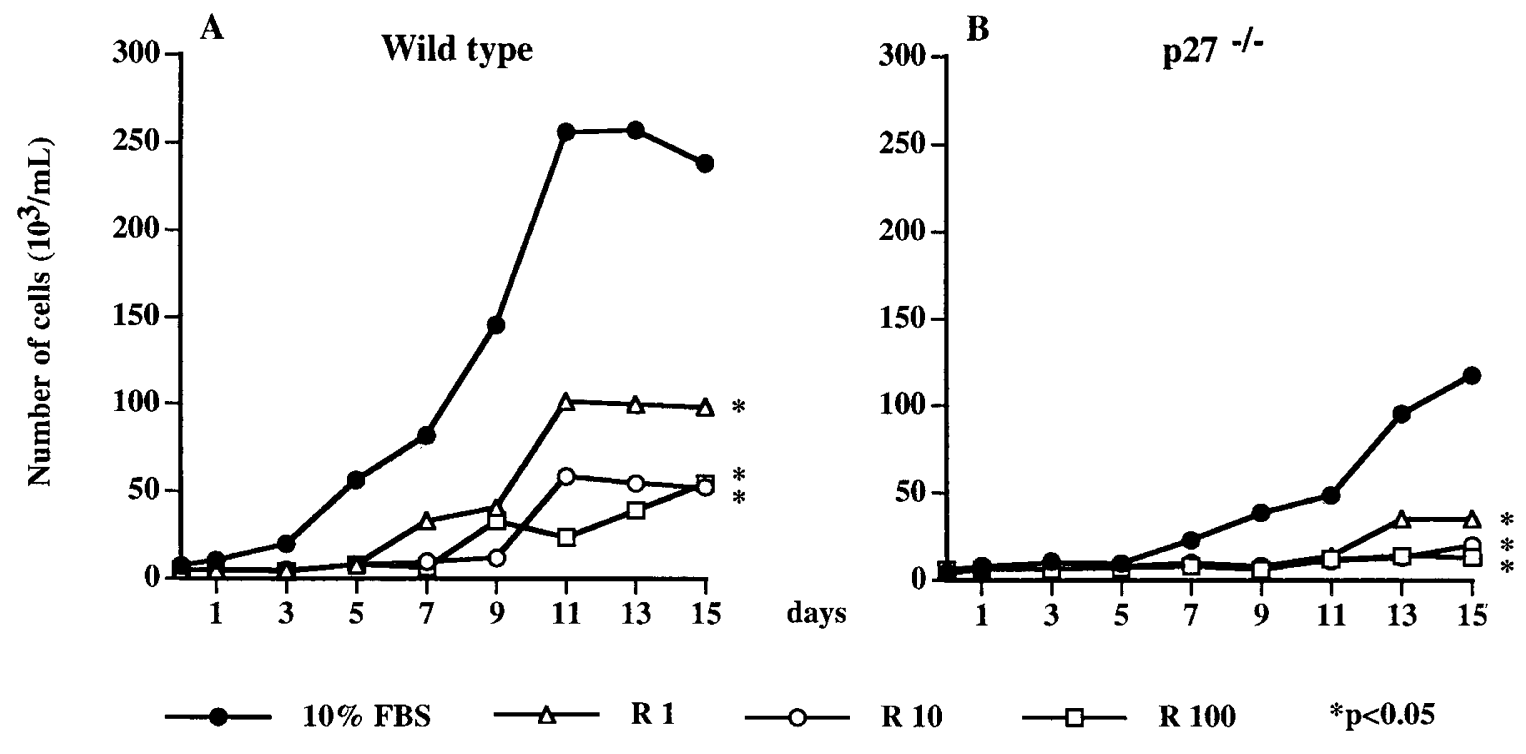

Figure 3.

Effect of rapamycin on mouse aortic smooth muscle cell (SMC) proliferation. A, WT; B, p27 -/- SMC grown in 10\% fetal bovine serum (FBS), alone or in the presence of $1 \mathrm{ng} / \mathrm{ml}(R 1), 10 \mathrm{ng} / \mathrm{ml}(R 10)$, and $100 \mathrm{ng} / \mathrm{ml}(R 100)$ of rapamycin, Treatment with rapamycin blocked proliferation of WT and p27 -/- cells. Data represent the average of five experiments.

hours reduced the proliferative index by $3 \% \pm 1 \%$ in WT ( $p=0.0004$ versus baseline) and $5 \% \pm 1 \%$ in $\mathrm{p} 27$ $-/-$ cells $(p=0.07)$ (Fig. 5).

\section{Rapamycin Alters p27 Expression and Apoptosis In Vitro}

In cultured p27 -/- SMC, p27 expression was not detected, as expected (Fig. 6). In WT cells, p27 was expressed in $5 \% \pm 2 \%$ of cells incubated with $10 \%$ FBS at baseline conditions (Fig. 7); increased expression $(32 \% \pm 6 \% ; p=0.03)$ was found with exposure to rapamycin.

Apoptosis was detected in $7.5 \% \pm 1 \%$ of WT cells, and $1 \% \pm 0.5 \%$ of $p 27-/-$ cells at baseline $p=$ 0.004). Rapamycin enhanced apoptosis in both cell lines to $15 \% \pm 2 \%(p=0.01$ versus baseline) and
$19 \% \pm 4 \%(p=0.009)$, for WT and p27 $-/-$ cells, respectively (Fig. 8).

\section{Discussion}

Targeting cell-cycle regulation is a potential therapeutic approach to control SMC proliferation. SMC proliferation is thought to be critical to the development of vascular occlusive lesions such as restenosis after coronary interventions, post-transplantation vasculopathy, and other forms of accelerated atherosclerosis. This study examined the role of p27, a negative cell-cycle regulator, on the vessel wall response to injury. The effects of rapamycin in the presence and absence of p27 were also studied, because rapamycin reduces intimal hyperplasia after injury through mod- 


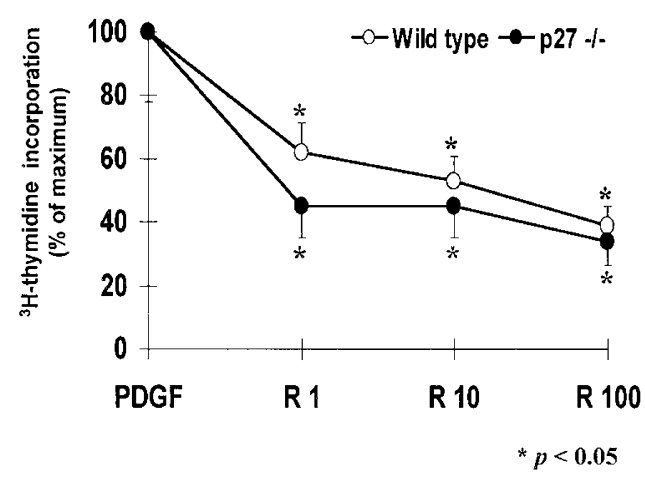

Figure 4.

In vitro effect of rapamycin on mouse aortic SMC DNA synthesis. ${ }^{3} \mathrm{H}$-thymidine incorporation in WT and p27 - /- cells after 24-hour exposure to $10 \mathrm{ng} / \mathrm{ml}$ of PDGF + rapamycin, at doses of $1 \mathrm{ng} / \mathrm{ml}(R 1), 10 \mathrm{ng} / \mathrm{ml}(R 10)$, and $100 \mathrm{ng} / \mathrm{ml}$ $(R 100)$. Results are expressed as percentage of ${ }^{3} \mathrm{H}$-thymidine uptake over the maximum obtained with PDGF alone. Data correspond to the average of four experiments.

$\square$ Wild-type $\mathbf{D} 27-/-$

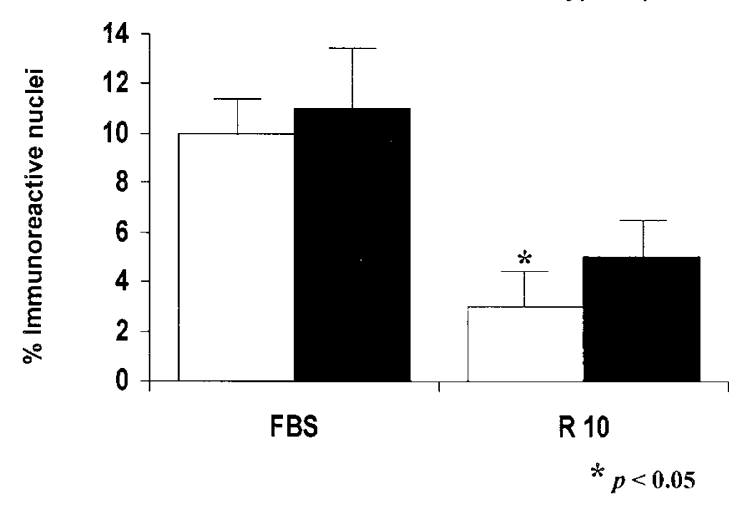

Figure 5.

In vitro effect of rapamycin on mouse aortic SMC Ki67 proliferative index. Proliferation index was assessed by measurement of the number of Ki67immunoreactive nuclei per field. The assessment was performed after a 72-hour treatment with either FBS or rapamycin $10 \mathrm{ng} / \mathrm{ml}$ (R10). Results are expressed as the percentage of immunoreactive cells.

ulation of p27 levels. In the mouse model of femoral arterial injury, lack of p27 did not alter the vessel wall intimal hyperplasia. Additionally, rapamycin reduced intimal hyperplasia in both WT and p27 -/-mice. Moreover, rapamycin decreased proliferation and enhanced apoptosis of mouse aortic SMC in culture. These findings corroborate a p27-independent mechanism for the inhibitory effect of rapamycin on SMC proliferation and neointimal formation.

Intracellular levels of p27 determine the threshold for cell-cycle progression through $\mathrm{S}$ phase. p27 is implicated in cell-cycle arrest mediated by cAMP (Kato et al, 1994), transforming growth factor- $\beta$ (Koff et al, 1993), and rapamycin (Nourse et al, 1994). p27 levels are regulated through translational (Hengst and Reed, 1996) and post-translational control by proteolytic degradation (Pagano et al, 1995). Growth factors released at the site of injury, such as PDGF, inhibit p27 synthesis in vitro (Agrawal et al, 1996), which may explain the rapid down-regulation of p27 and subse- quent increase in cell proliferation in the vessel wall after injury (Reis et al, 1999; Tanner et al, 1998).

Cells lacking p27 have a shortened G1 phase (Coats et al, 1996). p27 -/- mice exhibit multiple organ hyperplasia caused by generalized hypercellularity, which is most prominent between 4 to 8 weeks of age (Fero et al, 1996; Kiyokawa et al, 1996; Nakayama et al, 1996). p27 -/- mice also have an increased incidence of tumors, consistent with the body of evidence attributing a protective role to p27 in the progression and prognosis of proliferative diseases such as cancer (Catzavelos et al, 1997; Cordon-Cardo et al, 1998; Loda et al, 1997; Ophascharoensuk et al, 1998). These observations led to the hypothesis that the lack of p27 would enhance intimal proliferation after injury. In this study, p27 -/- mice underwent arterial injury at 6 weeks of age, to maximize potential differences in response to injury at a time when p27 absence has the highest influence on growth and development. However, the results show that intimal response to injury is not altered by lack of p27 in this murine model.

Treatment of cultured SMC with growth factors is widely used as a model of SMC proliferation associated with arterial injury. In the current study, no differences in PDGF-inducible ${ }^{3} \mathrm{H}$-thymidine incorporation at 24 hours, or in Ki67 immunoreactivity at 24 hours were seen between WT and p27 -/- cells. This agrees with previous in vitro studies showing similar responses to mitogens in WT and p27 -/- embryonic fibroblasts and T cells (Nakayama et al, 1996). In contrast, prolonged measurements of cell numbers suggest that, surprisingly, p27 -/- SMC have an increased doubling time during log-phase growth. The up-regulation of other CDK inhibitors, such as p21 and p16, compensating for the lack of p27 might account for these results (Casaccia-Bonnefil et al, 1999; Kiyokawa and Koff, 1998). Other mechanisms of CDK inactivation, such as increased inhibitory CDK phosphorylation, may also play a role (Hengst and Reed, 1998). Our results also suggest that short-term measures of cell proliferation, such as ${ }^{3} \mathrm{H}$-thymidine incorporation or Ki67 immunoreactivity, may not be sufficient to detect alterations in cell growth that occur over a 1 to 3 week period. Additionally, abnormalities identified in cell culture may not accurately reflect the in vivo setting, where no changes in intimal hyperplasia were seen between the p27 -/- and WT mice.

Rapamycin is a potent inhibitor of vascular SMC proliferation and migration (Marx et al, 1995; Poon et al, 1996). Regulation of p27 levels has been suggested to be critical for the antiproliferative effect of rapamycin (Chellappan et al, 1998; Luo et al, 1996). Antibodies to p27 eliminate its inhibitory activity in rapamycintreated cells, suggesting that increased levels of p27 are responsible for this inhibition (Nourse et al, 1994). In previous studies, we and others demonstrated that rapamycin reduces intimal hyperplasia after experimental balloon angioplasty (Burke et al, 1999; Gallo et al, 1999; Morris et al, 1995). Levels of p27 were increased and pRB phosphorylation was inhibited in the vessel wall of rapamycin-treated animals (Gallo et 


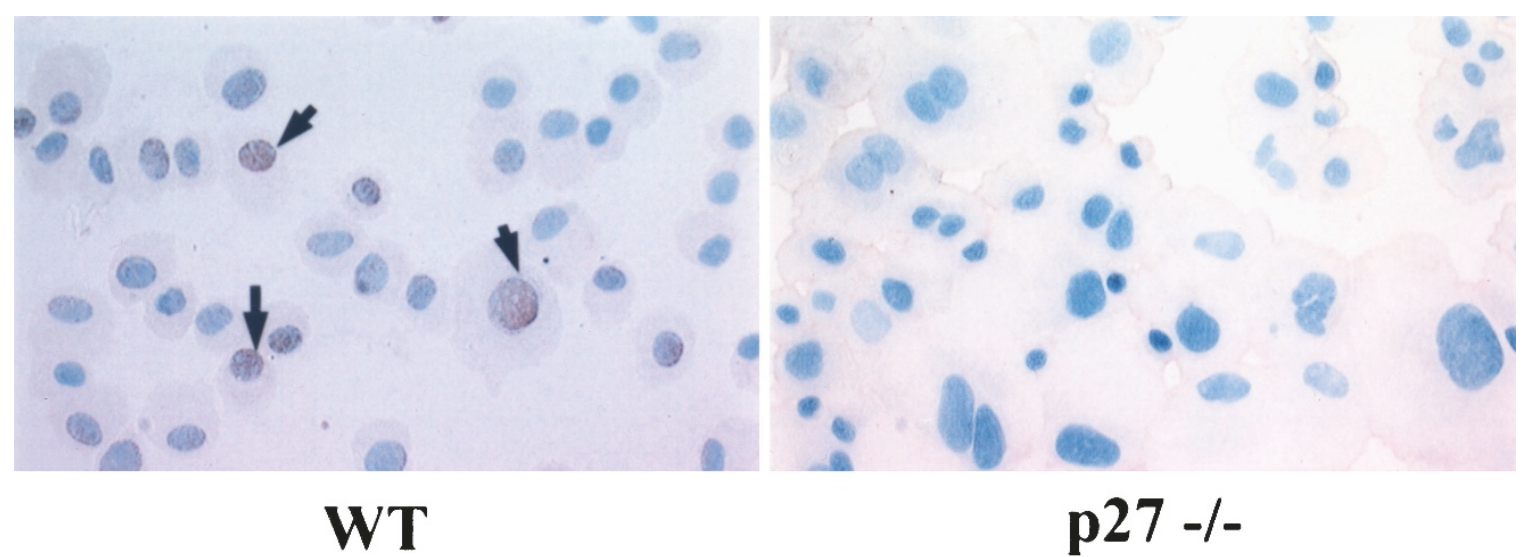

Figure 6.

Expression of p27 in mouse aortic SMC. Expression of p27 was present in WT but absent in p27 -/- SMC. Expression of p27 is identified by brown nuclear immunoreactivity (arrows).

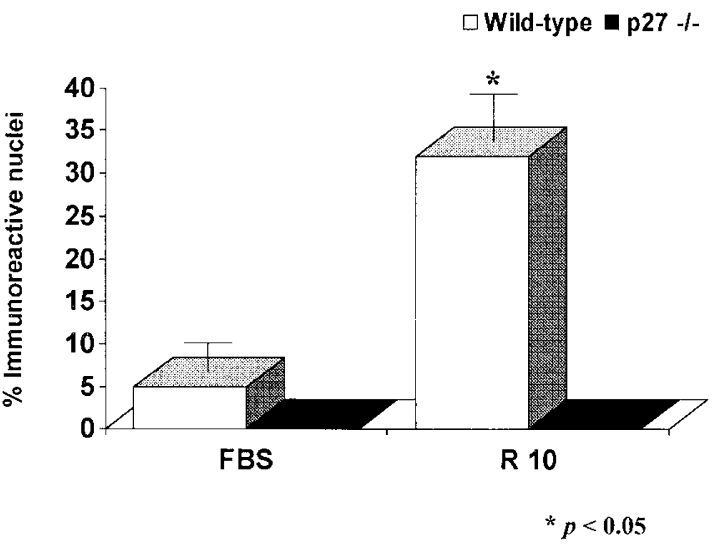

Figure 7.

Effect of rapamycin on 277 expression in mouse aortic SMC. Immunohistochemistry for p27 in WT and p27 -I- SMC was performed after a 72-hour treatment with either FBS or rapamycin $10 \mathrm{ng} / \mathrm{ml}(R 10)$. Results are expressed as the mean percentage of immunoreactive cells.

al, 1999). In addition to the effect on p27 modulation, a p27-independent mechanism of action was postulated for rapamycin because of studies showing that rapamycin inhibits in vitro proliferation of $\mathrm{T}$ lymphocytes and fibroblasts from p27 +/+ and p27 -/mice comparably (Luo et al, 1996; Nakayama et al, 1996).

Exposure of cultured SMC to rapamycin resulted in a dose-dependent inhibition of cell proliferation in both WT and p27 -/- SMC. In vivo, rapamycin reduced intimal hyperplasia formation 4 weeks after injury, independent of p27 genotype. Rapamycin delays cell-cycle progression at the G1/S and G2/M transition points, but it does not completely block proliferation. Inhibition is usually no higher than $50 \%$ to $70 \%$, suggesting that cells may still proliferate with an increased doubling time (Marx et al, 1995; Terada et al, 1993). These data are consistent with our findings of a $50 \%$ reduction in the lesion area, and inhibition of DNA synthesis by $40 \%$ to $60 \%$ in both WT and p27 -/-SMC. These results support the concept that rapamycin acts through p27-independent mech-

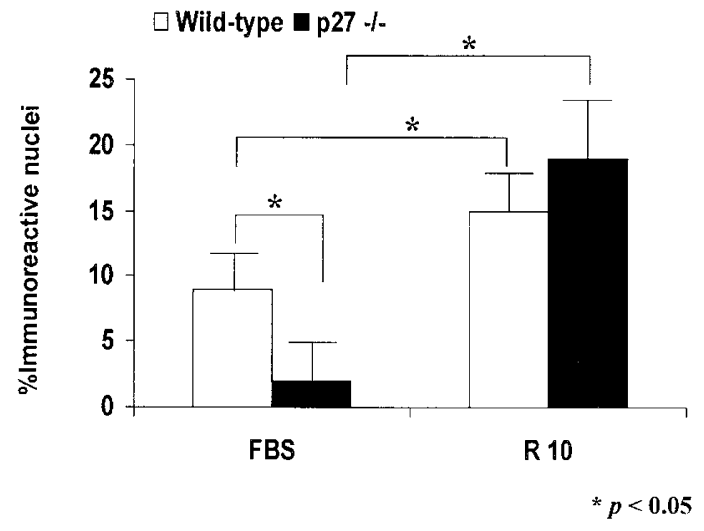

Figure 8.

Effect of rapamycin on apoptosis in mouse aortic SMC. Evaluation of apoptosis rates in WT and p27 -/- SMC, after a 72-hour treatment with either FBS or rapamycin $10 \mathrm{ng} / \mathrm{ml}(R 10)$. Results are expressed as the mean percentage of TUNEL-positive cells.

anisms, in addition to the previously reported p27dependent mechanisms of action.

Inhibition of proliferation or migration could account for the in vivo effect of rapamycin on intimal hyperplasia. Although we demonstrated in vitro inhibition of SMC proliferation, the possibility of an effect on migration cannot be excluded. Other in vitro studies showed that rapamycin blocks proliferation as well as migration (Marx et al, 1995; Poon et al, 1996). For instance, PDGF, suggested to have a role in processes caused by an excessive fibroproliferative response such as atherosclerosis and pathologic vessel healing, induces migration and proliferation through distinct pathways (Bornfeldt et al, 1995; Kundra et al, 1994). To our knowledge, no link has been established between p27 and cell migration pathways. p27 is likely to only be involved in proliferation; therefore, rapamycin's major effect in vivo may be through migration. This would explain the similar reductions in intimal hyperplasia obtained in WT and p27 -/- mice.

In this study, the in vitro inhibitory effect of rapamycin was mediated through decreased proliferation and enhanced apoptosis. At baseline, apoptosis rates 
were lower in p27 -/- SMC. Rapamycin enhanced apoptosis in both WT and p27 -/- cells; however, higher rates were found in p27 -/- than WT cells. A link between p27 and apoptosis was suggested in a study where p27 reconstitution rescued serumstarved p27 -/- cells from apoptosis, implying a protective effect of p27 against programmed cell death (Hiromura et al, 1999). In our experiments, cells were grown in the presence of growth factors at all times and, therefore, the mechanism of rapamycininduced apoptosis may be different. Similar proapoptotic effects of rapamycin were previously shown in several cell lines (Hosoi et al, 1999; Muthukkumar et al, 1995). Induction of p53-independent apoptosis and blockade of bcl-2 induction by rapamycin are among the proposed mechanisms (Hosoi et al, 1999; Miyazaki et al, 1995).

In summary, this study demonstrated that the mechanism of action for the antiproliferative effect of rapamycin is p27-independent, and that a lack of p27 does not affect the development of intimal hyperplasia in response to injury. Inhibition of SMC proliferation or migration could have mediated the reduction in intimal hyperplasia by rapamycin. Additionally, the in vitro effect of rapamycin seemed to be mediated by both decreased proliferation and enhanced apoptosis. These findings support the concept that regulation of cellular mechanisms of proliferation and apoptosis might be used in a therapeutic context to control intimal hyperplasia. Additional studies involving the use of animal models deficient in other CDK inhibitors or cell-cycle regulators, and atherosclerotic mice may bring additional insight into mechanisms and therapeutic approaches.

\section{Materials and Methods}

\section{Animals and Experimental Design}

Sixty-one WT and p27 -/- male and female mice, of the C57BL/SV129 strain, were used. p27 -/- mice were generated by targeted mutagenesis and previously characterized (Fero et al, 1996; Kiyokawa et al, 1996; Nakayama et al, 1996). For this study, littermate mice were bred from p27 heterozygous pairs, provided by Dr. A. Koff, Memorial Sloan Kettering Cancer Center, New York City, New York. Genotype was confirmed by immunoblotting blood samples with an affinity-purified p27 rabbit polyclonal antibody (1:3000 dilution), as described (Park et al, 1999). Animals were housed at the Center for Laboratory Animal Sciences, The Mount Sinai Medical Center, New York City, New York, and received standard rodent chow (PMI Nutrition International, St. Louis, Missouri) and tap water ad lib. Procedures were approved by the Institutional Animal Care and Use Committee, and carried out in accordance with the "Guide for the Care and Use of Laboratory Animals" (National Research Council, 1996).

For the in vivo study, WT $(n=30)$ and p27 $-/-(n=$ 31) mice underwent femoral artery injury, and were allocated to receive either rapamycin (Sirolimus, pro- vided by Dr. S. Sehgal, Wyeth-Ayerst, Princeton, New Jersey) suspended in a vehicle solution of $0.2 \%$ sodium carboxymethylcellulose and $0.25 \%$ polysorbate 80 , or an equal volume of vehicle solution, used as control treatment. Rapamycin was administered 48 hours before the intervention at a loading dose of 1.5 $\mathrm{mg} / \mathrm{kg}$, ip, and followed by $1 \mathrm{mg} / \mathrm{kg}$ per 48 hours, ip, for 2 weeks. To assess intimal hyperplasia, mice were euthanized 4 weeks after arterial injury.

\section{Femoral Artery Trans/uminal Injury}

Mice underwent bilateral femoral artery injury at 6 to 8 weeks of age. General anesthesia was achieved with pentobarbital sodium injection (Nembutal, Abbott Laboratories, North Chicago, Illinois), $40 \mathrm{mg} / \mathrm{kg}$ of body weight, ip. The femoral artery was exposed through a groin incision under a surgical microscope (Carl Zeiss, Thornwood, New York). Transluminal arterial injury was achieved by three passages of a 0.25-mm diameter angioplasty guidewire (Advanced Cardiovascular Systems, Tamecula, California) (Reis et al, 1998; Roque et al, 2000). After clamping the femoral vessels at the level of the inguinal ligament, an arteriotomy was made distal to the inferior epigastric artery, the guidewire inserted, the clamp removed, and the wire advanced to the level of the aortic bifurcation and pulled back. After removal of the wire, the arteriotomy site was ligated. This model is associated with significant intimal hyperplasia; I/M ratios of $1: 1$ by 4 weeks.

\section{Mouse Aortic SMC Culture Studies}

SMC were obtained from thoracic aortas of 4- to 6 -week-old p27 -/- and WT mice. Adventitia and endothelium were removed after digestion of the aortic segments with collagenase type II (Worthington, Lakewood, New Jersey). The media was further digested with collagenase and elastase (Sigma, St. Louis, Missouri), which yielded approximately 100,000 cells/aorta. Cells were grown in Dulbecco's modified essential medium (DMEM) containing 10\% FBS, 100 $\mathrm{U} / \mathrm{ml}$ of penicillin, and $100 \mu \mathrm{g} / \mathrm{ml}$ of streptomycin, and incubated at $37^{\circ} \mathrm{C}$ with $5 \% \mathrm{CO}_{2}$. SMC lineage was confirmed by presence of immunoreactivity for $\alpha$-actin (Alkaline Phosphatase-Conjugated Monoclonal Anti$\alpha$-Smooth Muscle Actin; Sigma; 1:100) in more than $90 \%$ of the cells. All experiments were performed using passages 3 to 5 .

To assess proliferation, cells were plated in 12-well dishes at a density of $6 \times 10^{3}$ cells $/ \mathrm{ml}$, in the presence or absence of different concentrations of rapamycin (1 $\mathrm{ng} / \mathrm{ml}, 10 \mathrm{ng} / \mathrm{ml}$, and $100 \mathrm{ng} / \mathrm{ml})$. Fresh rapamycin was added with each medium change every 48 hours. At 1 , $3,5,7,9,11,13$, and 15 days after plating, wells were trypsinized and counted in a hemocytometer.

DNA synthesis was determined by ${ }^{3} \mathrm{H}$-thymidine incorporation. SMC were plated in 12-well dishes $(6 \times$ $10^{3} \mathrm{cells} / \mathrm{ml}$ ) and incubated for 24 hours in DMEM supplemented with $1 \%$ FBS. Cells were washed in phosphate buffered saline (PBS) and incubated for 24 
hours with $1 \mu \mathrm{Ci}$ of ${ }^{3} \mathrm{H}$-thymidine in DMEM + PDGF (10 ng/ml), in the presence or absence of rapamycin, precipitated with $10 \%$ trichloroacetic acid for 60 minutes at $4^{\circ} \mathrm{C}$, and solubilized with $0.1 \mathrm{~N} \mathrm{NaOH}$. Radioactivity was measured in a liquid scintillation counter. These experiments were performed in triplicate, using quadruplicate wells.

\section{Histology, Immunohistochemistry, and TUNEL Assay}

For harvesting of specimens, perfusion-fixation was performed with 4\% paraformaldehyde in PBS at 100 $\mathrm{mmHg}$ for 4 to 6 minutes, followed by en bloc excision of both hindlimbs. Specimens were fixed overnight in 4\% paraformaldehyde in PBS and decalcified overnight in $10 \%$ formic acid. Two 2-mm-thick transverse segments were cut from each thigh at the level of injury in the common femoral artery and processed for paraffin embedding. Sections were stained with modified elastic tissue-Masson trichrome (Garvey, 1984).

Arterial cross-sections were analyzed using computerized morphometry (Software: NIH Image 1.60). Using the two sections obtained from each artery, the section with maximal luminal narrowing was selected for the measurements of luminal area, medial area, intimal area, vessel area, and lengths of the internal elastic lamina and external elastic lamina. Percentage of stenosis and I/M ratio were calculated as described previously (Gallo et al, 1999; Roque et al, 2000). Arteries with occlusive thrombi were excluded from the morphometric analysis.

To assess expression of p27 and Ki67 (a marker of cell proliferation) and apoptosis rates, WT and p27 - - - aortic SMC were incubated in $10 \%$ FBS in the presence or absence of rapamycin $(10 \mathrm{ng} / \mathrm{ml})$ for 72 hours, spun onto glass slides, and fixed in methanolacetone (50/50 v/v). Slides were immunohistochemically reacted for $\mathrm{Ki} 67$, and $\mathrm{p} 27^{\mathrm{kip} 1}$. Sections were incubated for 1 hour at room temperature with primary antibodies to Ki67 (1:1000; rabbit polyclonal antibody, NovoCastra, Newcastle, United Kingdom), and p2 $7^{\text {kip1 }}$ (1:1000; affinity-purified rabbit polyclonal antibody raised against a glutathione $S$-transferase fulllength murine p27 fusion protein [provided by Dr. A. Koff, Memorial Sloan-Kettering Cancer Center, New York City, New York]). A biotinylated goat anti-rabbit IgG antibody (1:1000; Vector Laboratories, Burlingame, California) was applied for 45 minutes, followed by avidin-biotin peroxidase complexes (1:25; Vector Laboratories) for 30 minutes. Diaminobenzidine was used as the final chromogen, and hematoxylin for nuclear counterstaining. Negative controls were prepared by substituting the primary for an irrelevant antibody. The positive controls were mouse lymph node for Ki67 and mouse thymus for p27.

Apoptosis was evaluated by the terminal deoxytransferase-mediated dUTP-biotin nick endlabeling (TUNEL) method. This assay was a modification of that described originally (Gavrieli et al, 1992), and was based on the specific binding of terminal deoxinucleotinyl transferase (TdT) to $3^{\prime}-\mathrm{OH}$ ends of DNA, to ensure the synthesis of a polydeoxynucle- otide. After exposure of nuclear DNA by proteolytic treatment, TdT was used to incorporate biotinylated deoxyuridine at sites of DNA breaks. The signal was amplified by avidin-biotin peroxidase complexes, and visualized by diaminobenzidine deposition, enabling conventional histochemical identification of reactive nuclei by light microscopy. Positive controls for TUNEL were moderately (2 rads) and severely (10 rads) irradiated mouse thymuses harvested 8 hours after irradiation.

Quantitation of immunolabelled cells was performed using high-power magnification $(\times 400)$; immunoreactive cells were identified by brown nuclear reactivity. Six high-power fields per slide were analyzed. The number of immunoreactive cells was normalized to the total number of cells in the vessel wall, and results were expressed as percentages. All sections were analyzed by two investigators blinded to the study design.

\section{Statistical Analysis}

Numerical data were expressed as mean \pm SEM. A two-tailed, unpaired $t$ test was used to compare data between WT and p27 -/- mice, and between untreated and rapamycin-treated groups. $P$ values $<0.05$ were regarded as significant.

\section{Acknowledgements}

The authors thank Marija Drobnjak and Maria Socorro Jiao for assistance in the immunohistochemistry and TUNEL assays. We also thank the personnel of the Center for Laboratory Animal Science for their help in maintaining the well being of the animals.

\section{References}

Agrawal D, Hauser P, McPherson F, Dong F, Garcia A, and Pledger WJ (1996). Repression of p2 $7^{\mathrm{kip} 1}$ synthesis by platelet-derived growth factor in BALB/c3T3 cells. Mol Cell Biol 16:4327-4336.

Bornfeldt KE, Raines EW, Graves LM, Skinner MP, Drebs EG, and Ross R (1995). Platelet-derived growth factor. Distinct signal transduction pathways associated with migration versus proliferation. Ann NY Acad Sci 766:416-430.

Braun-Dullaeus RC, Mann MJ, and Dzau VJ (1998). Cell cycle progression. New therapeutic target for vascular proliferative disease. Circulation 98:82-89.

Burke SE, Lubbers NL, Chen YW, Hsieh GC, Mollison KW, Luly JR, and Wegner CD (1999). Neointimal formation after balloon-induced vascular injury in Yucatan minipigs is reduced by oral rapamycin. J Cardiovasc Pharmacol 33:829835.

Casaccia-Bonnefil, Hardy RJ, Teng KK, Levine JM, Koff A, and Chao MV (1999). Loss of p27 $7^{\mathrm{kip} 1}$ function results in increased proliferative capacity of oligodendrocyte progenitors but unaltered timing of differentiation. Development 126:4027-4037.

Casscells W (1992). Migration of smooth muscle and endothelial cells: Critical events in restenosis. Circulation 86:723729 . 
Catzavelos C, Bhattacharya N, Ung YC, Wilson JA, Roncari L, Sandhu C, Shaw P, Yeger H, Morave-Protzner I, Kapusta L, Franssen E, Pritchard KI, and Slingerland JM (1997). Decreased levels of the cell-cycle inhibitor p2 $7^{\text {kip } 1}$ protein: Prognostic implications in primary breast cancer. Nat Med 3:227-230.

Chang MW, Barr E, Seltzer J, Jiang Y, Nabel GJ, Nabel EG, Parmacek MS, and Leiden JM (1995). Cytostatic gene therapy for vascular proliferative disorders with a constitutively active form of the retinoblastoma gene product. Science 267:518-522.

Chellappan SP, Giordano A, and Fisher PB (1998). Role of cyclin-dependent kinases and their inhibitors in cellular differentiation and development. Curr Top Microbiol Immunol 227:57-103.

Chen D, Krasinski K, Sylvester A, Chen J, Nisen P, and Andrés V (1997). Downregulation of cyclin-dependent kinase 2 activity and cyclin A promoter activity in vascular smooth muscle cells by $\mathrm{p} 27^{\mathrm{kip} 1}$, an inhibitor of neointima formation in the rat carotid artery. J Clin Invest 99:2334-2341.

Coats S, Flanagan WM, Nourse J, and Roberts JM (1996). Requirement of $\mathrm{p} 27^{\mathrm{kip} 1}$ for restriction point control of the fibroblast cell cycle. Science 272:877-880.

Cordon-Cardo C, Koff A, Drobnjak M, Capodieci P, Osman I, Millard S, Gaudin PB, Fazzari M, Zhang ZF, Massague J, and Scher HI (1998). Distinct altered patterns of p2 $27^{\mathrm{kip} 1}$ gene expression in benign prostatic hyperplasia and prostatic carcinoma. J Natl Cancer Inst 90:1284-1291.

Dumont FJ and Su Q (1996). Mechanism of action of the immunosuppressant rapamycin. Life Sci 58:373-395.

Fero ML, Rivkin M, Tasch M, Porter P, Carow CE, Firpo E, Polyak K, Tsai LH, Broudy V, Perlmutter RM, Kaushansky K, and Roberts JM (1996). A syndrome of multiorgan hyperplasia with features of gigantism, tumorigenesis, and female sterility in p27 $7^{\text {kip1 }}$-deficient mice. Cell 85:733-744.

Foegh M and Virmani R (1993). Molecular biology of intimal proliferation. Curr Opin Cardiol 8:938-955.

Gallo R, Padurean A, Jayaraman T, Marx SO, Roque M, Adelman S, Chesebro JH, Fallon JT, Fuster V, Marks AR, and Badimon JJ (1999). Inhibition of intimal thickening after balloon angioplasty in porcine coronary arteries by targeting regulators of the cell cycle. Circulation 99:2164-2170.

Garvey W (1984). Modified elastic tissue-Masson stain. Stain Technol 59:213-214.

Gavrieli Y, Sherman Y, and Ben-Sasson SA (1992). Identification of programmed cell death in situ via specific labeling of nuclear DNA fragmentation. J Cell Biol 119:493-501.

Hengst $L$ and Reed SI (1996). Translational control of $p 27^{\text {kip1 }}$ accumulation during the cell cycle. Science 271:1861-1864.

Hengst $L$ and Reed SI (1998). Inhibitors of the Cip/Kip family. Curr Top Microbiol Immunol 227:25-41.

Hiromura K, Pippin JW, Fero ML, Roberts JM, and Shankland SJ (1999). Modulation of apoptosis by the cyclin-dependent kinase inhibitor p27 ${ }^{\mathrm{kip} 1}$. J Clin Invest 103:597-604.

Hosoi H, Dilling MB, Shikata T, Liu LN, Shu L, Ashmun RA, Germain GS, Abraham RT, and Houghton PJ (1999). Rapamycin causes poorly reversible inhibition of mTOR and induces p53-independent apoptosis in human rhabdomyosarcoma cells. Cancer Res 59:886-894.
Kato JY, Matsuoka M, Polyak K, Massague J, and Sherr CJ (1994). Cyclin AMP-induced G1 phase arrest mediated by an inhibitor (p27Kip1) of cyclin-dependent kinase 4 activation. Cell 79:487-496.

Kiyokawa H, Kineman RD, Manova-Todorova KO, Soares VC, Hoffman ES, Ono M, Khanam D, Hayday AC, Frohman LA, and Koff A (1996). Enhanced growth of mice lacking the cyclin-dependent kinase inhibitor function of p27 ${ }^{\mathrm{kip} 1}$. Cell 85:721-732.

Kiyokawa H and Koff A (1998). Roles of cyclin-dependent kinase inhibitors: Lessons from knockout mice. Curr Top Microbiol Immunol 227:105-120.

Koff A, Ohtsuki M, Polyak K, Roberts JM, and Massague J (1993). Negative regulation of G1 in mammalian cells: Inhibition of cyclin E-dependent kinase by TGF-beta. Science 260:536-539.

Kundra V, Escobedo JA, Kazlauskas A, Kim HK, Rhee SG, Williams LT, and Zetter BR (1994). Regulation of chemotaxis by the platelet-derived growth factor receptor- $\beta$. Nature 367:474-476.

Li JM and Brooks G (1999). Cell cycle regulatory molecules (cyclins, cyclin-dependent kinases and cyclin-dependent kinase inhibitors) and the cardiovascular system: Potential targets for therapy? Eur Heart J 20:406-420.

Loda M, Cukor B, Tam SW, Lavin P, Fiorentino M, Draetta GF, Jessup JM, and Pagano M (1997). Increased proteasome-dependent degradation of the cyclin-dependent kinase inhibitor p27 in aggressive colorectal carcinomas. Nat Med 3:231-234.

Luo Y, Marx SO, Kiyokawa H, Koff A, Massagué J, and Marks A (1996). Rapamycin resistance tied to defective regulation of p27 ${ }^{\text {kip1. }}$. Mol Cell Biol 16:6744-6751.

MacLellan WR and Majesky MW (1997). Cell cycle regulators in vascular disease. Circulation 96:1717-1719.

Mann MJ, Whittemore AD, Donaldson MC, Belkin M, Conte MS, Polak JF, Orav EJ, Ehsan A, Dell'Acqua G, and Dzau VJ (1999). Ex-vivo gene therapy of human vascular bypass grafts with E2F decoy: The PREVENT single-centre, randomised, controlled trial. Lancet 354:1493-1498.

Marx SO, Jayaraman T, Go LO, and Marks AR (1995). Rapamycin-FKBP inhibits cell cycle regulators of proliferation in vascular smooth muscle cells. Circ Res 76:412-417.

Miyazaki T, Liu Z, Kawahara A, Minami Y, Yamada K, Tsujimoto Y, Barsoumian EL, Perlmutter RM, and Taniguchi T (1995). Three distinct IL-2 signaling pathways mediated by bcl-2, c-myc, and lck cooperate in hematopoietic cell proliferation. Cell 81:223-231.

Morishita R, Gibbons GH, Ellison KE, Nakajima M, von der Leyen H, Zhang L, Kaneda Y, Ogihara T, and Dzau VJ (1994). Intimal hyperplasia after vascular injury is inhibited by antisense cdk2 kinase oligonucleotides. J Clin Invest 93:14581464.

Morris RE, Cao W, Huang X, Gregory CR, Billingham ME, Rowan R, and Shorthouse RA (1995). Rapamycin (Sirolimus) inhibits vascular smooth muscle DNA synthesis in vitro and suppresses narrowing in arterial allografts and in ballooninjured carotid arteries: Evidence that rapamycin antagonizes growth factor action on immune and nonimmune cells. Transplant Proc 27:430-431. 
Muthukkumar S, Ramesh TM, and Bondada S (1995). Rapamycin, a potent immunosuppressive drug, causes programmed cell death in B lymphoma cells. Transplantation 60:264-270.

Nakayama K, Ishida N, Shirane M, Inomata A, Inoue T, Shishido N, Horii I, Loh DY, and Nakayama K (1996). Mice lacking $\mathrm{p} 27^{\mathrm{kip} 1}$ display increased body size, multiple organ hyperplasia, retinal dysplasia, and pituitary tumors. Cell 85 : 707-720.

National Research Council (1996). Guide for the care and use of laboratory animals. Washington, DC: National Academy Press.

Nourse J, Firpo E, Flanagan MW, Meyerson M, Polyak K, Lee MH, Massague J, Crabtree GR, and Roberts JM (1994). Rapamycin prevents IL-2-mediated elimination of the cyclinCDK inhibitor, p27 ${ }^{\mathrm{kip} 1}$. Nature 372:570-573.

Ophascharoensuk V, Fero ML, Hugher J, Roberts JM, and Shankland SJ (1998). The cyclin-dependent kinase inhibitor p2 $7^{\text {kip } 1}$ safeguards against inflammatory injury. Nat Med 4:575-580.

Pagano M, Tam SW, Theodoras AM, Beer-Romero P, Del Sal G, Chau V, Yew PR, Draetta GF, and Rolfe M (1995). Role of the ubiquitin-proteasome pathway in regulating abundance of the cyclin-dependent kinase inhibitor p27. Science 269: 682-685.

Park MS, Rosai J, Nguyen HT, Capodieci P, Cordon-Cardo C, and Koff A (1999). p27 and Rb are on overlapping pathways suppressing tumorigenesis in mice. Proc Natl Acad Sci USA 96:6382-6387

Polyak K, Lee MH, Erdjument-Bromage H, Koff A, Roberts JM, Tempst P, and Massague J (1994). Cloning of p2 $7^{\mathrm{kip} 1}$, a cyclin-dependent kinase inhibitor and a potential mediator of extracellular antimitogenic signals. Cell 78:59-66.

Poon M, Marx SO, Gallo R, Badimon JJ, Taubman MB, and Marks AR (1996). Rapamycin inhibits vascular smooth muscle cell migration. J Clin Invest 98:2277-2283.
Reis ED, Roque M, Zhang WX, Fallon JT, Weinberg $H$, Badimon JJ, and Taubman MB (1998). Neointimal hyperplasia after femoral artery transluminal injury in C57BL/6 and FVB mice. Surg Forum 49:303-305.

Reis ED, Roque M, Cordon-Cardo C, Fuster V, and Badimon JJ (1999). Time course of p27 expression after femoral arterial injury in the mouse. Surg Forum 50:482-483.

Roque M, Fallon JT, Badimon JJ, Zhang WX, Taubman MB, and Reis ED (2000). A mouse model of femoral artery denudation injury associated with the rapid accumulation of adhesion molecules on the luminal surface and recruitment of neutrophils. Arterioscler Thromb Vasc Biol 20:335-342.

Ross R (1999). Atherosclerosis: An inflammatory disease. N Engl J Med 340:115-126.

Sherr CJ and Roberts JM (1995). Inhibitors of mammalian G1 cyclin-dependent kinases. Genes Dev 9:1149-1163.

Sousa JE, Costa MA, Abizaid A, Abizaid AS, Feres F, Pinto IM, Seixas AC, Staico R, Mattos LA, Sousa AG, Falotico R, Jaeger J, Popma JJ, and Serruys PW (2001). Lack of neointimal proliferation after implantation of sirolimus-coated stents in human coronary arteries: A quantitative coronary angiography and three-dimensional intravascular ultrasound study. Circulation 103:192-195.

Tanner FC, Yang ZY, Duckers E, Gordon D, Nabel GJ, and Nabel EG (1998). Expression of cyclin-dependent kinase inhibitors in vascular disease. Circ Res 82:396-403.

Terada N, Lucas JJ, Szepesi A, Franklin RA, Domenico J, and Gelfand EW (1993). Rapamycin blocks cell cycle progression of activated T cells prior to events characteristic of the middle to late G1 phase of the cycle. J Cell Physiol 154:7-15. 